\title{
Od maturzysty do studenta - zdalna edukacja w perspektywie studentów I roku studiów
}

\author{
From high school graduate to student - remote education \\ in the perspective of students of the 1st year of study
}

\begin{abstract}
Streszczenie
Niniejszy artykuł przedstawia analizę teoretyczną oraz raport z wycinka badań prowadzonych wśród studentów pierwszego roku. W badaniach posłużyłam się wywiadem swobodnym, który pozwolił na poznanie, z perspektywy uczestników badania, interpretacji i przeżyć związanych ze zdalnym przygotowaniem do egzaminu maturalnego i studiowania. Analiza materiału miała charakter jakościowy. Główna problematyka artykułu koncentruje się wokół wielowymiarowości i złożoności problemów, których doświadczyli studenci przygotowujący się do matury w formie zdalnej, oraz tego, jak postrzegają pierwszy rok studiów w takiej formule. W perspektywie studentów pierwszego roku wiele wyzwań stoi przed nauczycielami i wykładowcami, wobec których oczekuje się reorganizacji zajęć, dostosowania metod nauczania do zajęć w formie zdalnej. Również studenci bogatsi o nowe doświadczenia nie są tymi samymi ludźmi, na nowo muszą nauczyć się funkcjonować w grupie i zbudować relacje. Badania ukazały także, że perspektywa zdalnej edukacji jest różna i nie można jednoznacznie określić jej negatywnego wpływu na społeczność szkolną i akademicką. Konieczna jest nowa perspektywa i wizja edukacji. Niewątpliwie jednak stawia ona wiele wyzwań wobec wszystkich uczestników edukacji, zarówno nauczycieli, jak i uczniów czy studentów.
\end{abstract}

1 Jolanta Konieczny, Instytut Badań nad Edukacją i Komunikacją, Politechnika Śląska, Polska, e-mail: jolanta.konieczny@polsl.pl, ORCID ID: https://orcid.org/0000-0003-0495-6141. 


\title{
Słowa kluczowe:
}

edukacja, pandemia, egzamin maturalny, student pierwszego roku, nauka zdalna

\begin{abstract}
This article presents a theoretical analysis and a report on a segment of research conducted among first-year students. In the research, In the research, I used a free interview, which allowed me to get to know the interpretation and experience related to remote preparation for the matriculation examination and study from the perspective of the research participants. The analysis of the material was qualitative. The main issue of the article focuses on the multidimensionality and complexity of the problems experienced by students preparing for the matura exams in a remote form and how they perceive the first year of studies in such a formula. In the perspective of first-year students, many challenges are faced by teachers and lecturers, who are expected to reorganize their classes and adapt teaching methods to remote classes. Also, students rich in new experiences are not the same people, they have to learn how to function in a group and build relationships again. Research has also shown that the perspective of remote education is different and its negative impact on the school and academic community cannot be clearly defined.
\end{abstract}

\section{Keywords:}

education, pandemic, matura exam, first-year student, remote learning

\section{ZAŁOŻENIA WSTĘPNE}

Pandemia COVID-19 wpłynęła na wszystkie sfery życia ludzi. Diametralnie zmieniła się codzienność każdego człowieka, jednak niewątpliwym i największym wyzwaniem, z jakim musieli zmierzyć się nauczyciele, uczniowie, rodzice, ale także władze, jest odejście od tradycyjnej infrastruktury, form i metod nauczania (Poleszak \& Pyżalski, 2020, s. 11), ale również rytmu dnia. Przed rozpoczęciem pandemii zdalna edukacja była tylko wyborem (Pyżalski, 2020, s. 3), najczęściej osób, które ze względu na obowiązki zawodowe czy rodzinne wybierały taki model edukacji, by poszerzyć swoje kwalifikacje, dostosowując proces ich nabywania do obowiązków zawodowych i rodzinnych.

Egzamin maturalny zawsze wiąże się z dużymi emocjami, natomiast w 2020 roku był wyjątkowo trudny ze względu na panującą pandemię COVID-19. Obecni studenci musieli zmierzyć się z nagłym zakończeniem edukacji stacjonarnej, przejść na pracę zdalną. Nauczyciele, którzy do tej pory byli ich mentorami- 
-przewodnikami, sami mieli trudności, by poradzić sobie w niecodziennej sytuacji. Nie sprzyjała również organizacja egzaminu maturalnego - zmiany w terminarzu matur, niepewność związana z ograniczeniami sanitarno-epidemiologicznymi. Pojawiające się sytuacje zakłócające proces przygotowania do egzaminu maturalnego mogły mieć wpływ na dobrostan uczniów. W niniejszej rozprawie przedstawiam perspektywę uczniów, jeśli chodzi o wydarzenia z marca 2020, ale również opinię o obecnej sytuacji studiowania i bycia „studentem zdalnym”. Moim celem było ukazanie, jak postrzegają siebie, relacje w grupie studenckiej, ale i jakość studiowania w tych jakże wyjątkowych czasach. Celem niniejszej rozprawy, jest przedstawienie analizy teoretycznej oraz wycinka badań prowadzonych wśród studentów I roku. Interesująca poznawczo jest ich perspektywa jako uczniów przygotowujących się do matury, a teraz zdalnych studentów.

W pierwszej części omawiam założenia metodologiczne prowadzonych badań, następnie dokonuję analizy teoretycznej, która zestawiona zostaje z wynikami przeprowadzonych badań. W założeniu zmiana struktury rozprawy ma pozwolić na przejrzyste przedstawienie perspektywy studentów, ich obaw, ale i trudności, z jakimi się borykali i których doświadczają do dziś, jednocześnie konfrontując je z perspektywą teoretyczną.

\section{BADANIA WŁASNE}

Prowadzone badania zostały osadzone w nurcie badań jakościowych. Metoda badawcza to wywiad swobodny, wybór takiej strategii badawczej pozwala na „uzyskanie interpretacji, sensów opisu świata, przeżyć osoby udzielającej wywiadu” (Kvale, 2004, s. 17). Uczestnicy badania mogli uzyskać bliższy kontakt ze mną, poczuć zaufanie, co w moim przekonaniu miało doprowadzić do szczerych wyznań i refleksji. Odpowiadali na pytania dotyczące przygotowania do egzaminu maturalnego w formie zdalnej, a także jakości prowadzonych zajęć podczas pierwszego roku studiów. Badania zostały przeprowadzone na terenie województwa śląskiego, wśród studentów i studentek I roku studiów Uniwersytetu Śląskiego i Politechniki Śląskiej, wywiady prowadzone były za pośrednictwem platformy Zoom. Uczestnicy badania wyrazili zgodę na nagrywanie wywiadów; w celu braku możliwości identyfikacji studentów i ich nauczycieli, o których opowiadają w wywiadach, nie zostają ujawnione żadne dane placówek, w których zdawali egzaminy maturalne. W niniejszej rozprawie przedstawione zostają fragmenty wywiadów z 10 uczestnikami badania. Szersze wyniki badań zostaną opublikowane w książce poświęconej niniejszemu projektowi. 
Celem przeprowadzonego badania było ukazanie opinii studentów I roku o przygotowaniu do matury i zdalnym kształceniu na poziomie ostatniej klasy szkoły średniej i obecnego I roku studiów na uczelni wyższej. Analiza literatury przedmiotu oraz przedstawiony cel badań pozwolił na wyłonienie następujących problemów badawczych:

1. Jak w opinii studentów I roku przebiegało przygotowanie do matury w formie zdalnej?

2. Jakie trudności pojawiły się podczas przygotowania do matury w formie zdalnej i w jaki sposób je pokonywali?

3. Jak studenci I roku studiów oceniają wpływ nauki zdalnej na jakość relacji z rówieśnikami?

4. Jak studenci I roku oceniają relacje w swojej grupie studenckiej?

\section{UCZEŃ-NAUCZYCIEL-SZKOŁA}

Do marca 2020 wiele polskich szkół funkcjonowało w transmisyjnym modelu szkoły, gdzie uczeń był jedynie odbiorcą wiedzy, natomiast kreatorem procesu uczenia, jedynym źródłem wiedzy był nauczyciel (Żylińska, 2013, s. 259). Obowiązek przejścia na zdalny tryb edukacji spowodował, iż niejednokrotnie to nauczyciel stawał się uczniem. Nie miał on również tak dużego bezpośredniego wpływu na uczniów, jak działo się to podczas zajęć w klasie. Spora część uczniów posiadała wyższe kompetencje cyfrowe niż nauczyciele. Ta nagła zamiana ról, gdzie uczniowie przebywali w świecie dla siebie doskonale znanym, a nauczyciele nabywali dopiero kompetencji, powodowała, iż niejednokrotnie rodziły się konflikty i frustracje.

S5: „Na początku to mnie nawet śmieszyło, kiedy nauczycielka nie miała pojęcia jak udostępnić prezentację i »z góry « zakładała, że skoro ona ją widzi to my też [...] Próbowaliśmy ją poinstruować co powinna zrobić, żebyśmy mogli zobaczyć prezentację, ale po kolejnej nieudanej próbie powiedziała, że koniec z Zoomami i będzie nam tylko wysyłała zadania na Messenger. Od tamtej pory, mimo interwencji u wychowawcy, język polski mieliśmy tylko w formie wysyłania poleceń przez nauczyciela, my odsyłaliśmy rozwiązania. Po czasie otrzymywaliśmy ocenę na Librusie z danego zadania. Był to początek kwietnia, także nie straciliśmy całego roku, ale niewątpliwie niełatwo jest przygotowywać się do matury bez wsparcia nauczyciela”. 
Wiele zarzutów pada pod adresem nauczycieli, kiedy poruszany jest temat zdalnej edukacji. Tymczasem większość z nich została pozostawiona samym sobie. Nie posiadali oni odpowiedniego przygotowania metodycznego, ale i sprzętu. Rozpoczęli oni zajęcia zdalne z bardzo dużą presją, wielu z nich po początkowych porażkach ostatecznie odnalazło się w nowej rzeczywistości, jednak nadal bardzo duży odsetek nie radzi sobie ze zdalną edukacją. W trakcie trwania pandemii powstało wiele raportów ukazujących stan polskiej edukacji, badacze wskazywali, iż nauczyciele nie poszerzają swoich kompetencji w zakresie rozwoju metodycznego, stosują metody podające, pełniąc tym samym rolę zleceniodawcy materiału do realizacji (Plebańska i in., 2021, s. 14-15). Zajęcia odbierane były przez uczniów jako mało atrakcyjne, nauczyciele nadmiernie skupiali się na przekazywaniu wiedzy w formie wykładu i fokusowali się na pracy z podręcznikiem (Ptaszek i in., 2020). Wielu badaczy, ale również rodziców i uczniów, oczekiwało, że wraz ze zmianą trybu uczenia zmieni się sposób nauczania, niestety zmiana z nauczającego w prowadzącego-kierującego działalnością edukacyjną uczniów wprowadza rewolucję, na którą wielu nauczycieli nie jest gotowych, gdyż odczytują taką zmianę jako utratę bezpośredniego wpływu na uczniów, tego, czego się uczą i w jaki sposób.

\section{DŁUGOTRWAŁA NIEPEWNOŚĆ ZMIENIA WSZYSTKO}

Sytuacja pandemii nie jest naturalna dla mózgu, który odczytuje sygnały płynące z otoczenia jako zagrożenie (Kaczmarzyk, 2020, s. 24). Długotrwały lęk nie wpływa korzystnie na działanie ludzkiego mózgu, blokuje jego zdolności poznawcze, swobodne przetwarzanie informacji, krytyczne i twórcze myślenie. Wiedza dostarczona z badań nad ludzkim mózgiem dowodzi, iż człowiek najlepiej zapamiętuje, kiedy występuje równowaga dobrostanu psychicznego i fizycznego. Długotrwały stres wywołany ciągłą niepewnością sytuacji, troską o zdrowie swoje i najbliższych, a także pogorszenie jakości relacji rówieśniczych oddziałują na jakość nauki. Stres wpływa na działanie hipokampa, który jest ośrodkiem w mózgu odpowiedzialnym za trwałe zapamiętywanie (Spitzer, 2014, s. 137).

Mając świadomość zagrożenia, jakie niesie długotrwała izolacja, zatracenie poczucia bezpieczeństwa, a także niepewność i troska o zdrowie swoje i najbliższych, wpływające na jakość edukacji uczniów ostatniej klasy szkoły średniej, którzy dodatkowo odczuwali niepokój związany ze zbliżającym się egzaminem maturalnym, wielu z nich w swoich wypowiedziach podkreślało, że towarzyszący im ciągły stres nie pomagał w przygotowaniach do egzaminów. 
S1: „Na początku, kiedy dowiedzieliśmy się, że przechodzimy na zdalną naukę to wszyscy się cieszyli, myśleliśmy, że to będą wakacje. Niestety szybko się okazało, że mamy więcej problemów niż się spodziewaliśmy, moi rodzice pracowali zdalnie to dodatkowo utrudniało mi naukę, bo słyszałam za ścianą jak mama prowadziła zajęcia i strasznie mi to przeszkadzało. Miałam taki etap, że cokolwiek by się nie działo to się denerwowałam, kłóciłam z rodzicami i w myślach błagałam, żeby wrócić do szkoły i odzyskać trochę przestrzeni dla siebie".

Niewątpliwie sytuacją stresującą była niepewność i troska o zdrowie swoje i najbliższych. Wielu uczniów borykało się z trudnościami związanymi z przejściem na kwarantannę domową, przebytą chorobą lub nawet śmiercią.

S10: „Trudno mi mówić o czasie przygotowania się do matur, bo u mnie takiego prawie w ogóle nie było. Tuż po przejściu na zdalną edukację okazało się, że na COVID-19 zachorowała moja ciocia, ponieważ miałam z nią kontakt byłam w kwarantannie. Ponieważ nikt z nas nie był obyty z taką sytuacją, byłam bardzo zestresowana, nie potrafiłam się na niczym skupić. W dziesiątym dniu kwarantanny sama zachorowałam i przez tydzień nie podnosiłam się z łóżka, wszystko mnie bolało, miałam bardzo wysoką gorączkę i duszności. Po zakończonej chorobie miałam bardzo duże problemy z koncentracją, zaczynałam rozwiązywać testy maturalne z matematyki, po czym nie pamiętałam prostego wzoru na pole kwadratu. Była to dla mnie niezwykle frustrująca sytuacja, czułam się bezsilna, chciałam nie podchodzić do egzaminów maturalnych. Ostatecznie jednak zdecydowałam się pójść mając nadzieję, że dwa i pół roku nauki nie były na marne. Maturę zdałam, ale myślę, że mogłam osiągnąć lesze wyniki. Nie chcę jednak bardzo tego rozpamiętywać, ponieważ najważniejsze jest dla mnie, że dostałam się na wymarzone studia i nie straciłam roku w oczekiwaniu na kolejne egzaminy maturalne”.

Wypowiedź studentki jest jedną z wielu podobnych, jakie usłyszałam podczas prowadzenia badań. Potwierdzają one, jak duże znaczenie ma dobrostan psychiczny i fizyczny w prawidłowym funkcjonowaniu i w nauce. Jeżeli nie zostaną zaspokojone najbardziej podstawowe potrzeby człowieka, jego organizm nie pozwoli na działania wyższego rzędu, gdyż cała energia organizmu zostanie przekazana do walki o zdrowie. Nieoceniona w takich sytuacjach była pomoc nauczycieli i rodziców, którzy również mieli trudności i kłopoty, ale jednocześnie stawali się wzorem do naśladowania, jak sobie radzić w sytuacjach kryzysowych. 
Wspólne dążenie do osiągnięcia równowagi psychicznej pozwalało na dążenie do założonych celów i motywowało do działania.

\section{MOTYWACJA}

Izolacja domowa, nauka zdalna mogły wpłynąć na obniżenie motywacji do angażowania się w zajęcia szkolne, naukę i odrabianie zadań domowych. Motywacja dotyczy przekonań, celów i wartości uczniów, które określają, jakie zadania będą wykonywać, a także utrzymywać ciągłość ich realizacji (Zaccoletti i in., 2020). Motywacja determinuje dążenie i osiągnięcie założonych celów (Jaszczyszyn i Szada-Borzyszkowska, 2010, s. 423). Szczególnie ważna jest, kiedy uczniowie przygotowują się do egzaminu maturalnego; obniżenie motywacji do działania, powtarzania materiału może mieć wypływ nie tylko na jego wyniki, ale również dobrostan psychiczny. Jednym z pytań wywiadu było podjęcie wątku motywacji do nauki, w jaki sposób wyzwalali motywację wewnętrzną, ale także jakie czynniki zewnętrzne determinowały ich działalność.

S1: „Kiedy dotarła do nas informacja, że przechodzimy na zdalny tryb uczenia się, to przyszła do nas Pani Pedagog i przedstawiła ten okres, który miał nadejść jako szansa dla nas na lepsze przygotowanie do matury. W bardzo atrakcyjny sposób przedstawiła wizję czasu wolnego, w którym będziemy tylko zajmowali się maturą. Niestety wizja ta nie miała przełożenia w późniejszym czasie, nauczyciele tak mocno zaangażowali się w zdalną edukację, że miałam wrażenie przesytu informacji i nadmiaru obowiązków. Musieliśmy logować się na zajęcia zdalne, do innego nauczyciela w określonym dniu wysłać rozwiązane zadania. Miałam poczucie bardzo dużego chaosu. Mogę stwierdzić, że moja motywacja do nauki bardzo mocno się obniżyła, kiedy chodziłam do szkoły miałam wszystko poukładane, chodziliśmy na dodatkowe fakultety i czułam wewnętrzny spokój, że dam radę osiągnąć założony wynik egzaminów maturalnych. Od kiedy zaczęła się zdalna edukacja nie panowałam nad niczym. Miałam wrażenie, że wszystko się dzieje poza mną, nie pomagały również przekładanie terminu egzaminu, naprawdę chciałam mieć to już za sobą a to czekanie powodowało, że coraz mniej się przygotowywałam mimo tego, że otrzymaliśmy więcej czasu niż wcześniejsze roczniki”.

Przytoczone słowa jednej ze studentek wskazują, jak ważne jest, by w trakcie zdalnego nauczania dbać o motywację do nauki; łatwo również jest zatracić się 
i przeciążać uczniów obowiązkami. Warto jednak zwrócić uwagę, że uczniowie szybko odnaleźli się w nowej rzeczywistości i wypracowali nowe schematy działania, które pozwalały im w przystępny dla siebie sposób „przetrwać” czas zdalnej edukacji.

S4: „Może to nie było zbyt dobre, ale bardzo szybko wypracowałam sobie schemat na jakie lekcje warto się starać a co mogę odpuścić. Sami nauczyciele również nie bardzo przekonywali do nauki tych, którzy nie zdawali matury z danego przedmiotu. Jednym z przykładów jest historia, gdzie od czasu zdalnej edukacji nie musiałam robić nic, bo nie podchodziłam do matury z tego przedmiotu. Podobnie było z chemią i biologią”.

S2: „Mam wrażenie, że nauczyły mnie czegoś tylko te lekcje, które odbywały się synchronicznie. Musiałam się postarać i przygotować, kiedyś ktoś wysyłał tylko materiał to większość z nas szukała odpowiedzi w Internecie, przerabiała i wysłała do nauczycielki”.

S6: „Strasznie mi się nie chciało uczestniczyć w zajęciach online miałam poczucie straty czasu. Wolałam sama poszukać materiałów i coś powtórzyć niż oglądać zwykły pokaz slajdów”.

S8: „Męczące było też ciągłe wykonywanie zadań, skanowanie ich i wysyłanie do nauczyciela, który nawet nie zawsze dawał odpowiedź tylko po jakimś czasie pojawiała się ocena w Librusie”.

W wypowiedziach studentów zauważyć można duże zagubienie, próby poszukiwania bezpiecznego wyjścia z sytuacji, poradzenia sobie z emocjami do tej pory nieznanymi. Wielu studentów relacjonuje przygotowania do egzaminu maturalnego jako jedną z największych sytuacji lęku i niepewności, abiturienci w roku 2020 musieli dodatkowo pogodzić się z nieoczekiwaną sytuacją samodzielnej organizacji przygotowań do egzaminów. Potwierdzeniem wypowiedzi studentów są badania przeprowadzone przez zespół badaczy z Uniwersytetu w Amsterdamie, którzy wykazali, iż wraz ze zmianą sytemu nauczania na zdalny, izolacją z grupy rówieśniczej, a także organizacji systemu nauczania obniżył się poziom motywacji do nauki (Meeter i in., 2020). Brak motywacji do jakichkolwiek działań determinował kolejną trudność, jaką było pogorszenie lub całkowity zanik relacji rówieśniczych. 


\section{RELACJE}

Szkoła to miejsce nie tylko nauki, ale również budowania relacji, gdzie niejednokrotnie kontakt z rówieśnikami i nauczycielami pomagał w radzeniu sobie w sytuacjach trudnych. Obowiązek szkolny nie wiąże się tylko z przyswajaniem wiedzy, ale również z kontaktem z innymi. Szkoła do czasów pandemii była pretekstem do budowania relacji (Ptaszek i in., 2020). Również z perspektywy biologii człowiek nie jest gotowy na izolację, nasze mózgi są tak skonstruowane, że potrzebują drugiego człowieka (Kaczmarzyk, 2020, s. 23).

S6: „W moim przypadku pandemia zweryfikowała moje przyjaźnie. Tuż po rozpoczęciu edukacji zdalnej współpracowaliśmy całą klasą, z czasem jednak nasz kontakt osłabł do tego stopnia, że dzisiaj pozostała mi tylko jedna koleżanka. Na początku się tym przejmowałam miałam taką potrzebę podtrzymywania tych relacji na siłę. Z czasem jednak mogę powiedzieć, że to było działanie bez sensu, lepiej mieć jedną przyjaciółkę, ale dobrą”. S10: „Moja klasa była bardzo ambitna, wszystkim zależało na wysokich wynikach egzaminów maturalnych. Większość zajęć mieliśmy na zasadzie wysyłania materiałów przez nauczyciela, spotykaliśmy się z nim sporadycznie na Skype i to właśnie wywołało bardzo duże konflikty w naszej klasie. Każdy z nas chciał konsultować coś z nauczycielem, byli tacy, którzy mają większą siłę przebicia i tym samym uzyskiwali większe wsparcie niż Ci czekający grzecznie na swoją kolejkę. Takie działanie niektórych spowodowało, że atmosfera była bardzo nieprzyjemna, dochodziło do kłótni w grupie na Facebooku, niektórzy się wzajemnie obrażali, a kiedy spotkaliśmy się na egzaminach to nawet ze sobą nie rozmawiali. Taka sytuacja spowodowała, że nie mam zbyt dużo znajomości, które pozostały po liceum. Mam dwie koleżanki z którymi utrzymuję kontakt i to tyle”.

Izolacja społeczna i konieczność nauki zdalnej mocno przełożyły się na jakość relacji w klasie i grupie studenckiej. Stosowane przez nauczycieli, w warunkach edukacji stacjonarnej, metody pobudzające do współpracy nie miały swojego przełożenia w zdalnej rzeczywistości. Nauczyciele borykali się z podstawowymi problemami związanymi z prowadzeniem lekcji online, dlatego nie byli w stanie wykorzystać rozbudowanych narzędzi pracy stymulujących do pracy w grupie. Współpraca jest elementem integrującym grupy, jednocześnie to najtrudniejszy wymiar relacji międzyludzkich (Klus-Stańska i Nowicka, 2005, s. 219). Analiza wypowiedzi studentów wskazuje, iż konieczna jest refleksja nad działalnością 
szkół i kierunkiem jej zmian. Ważne jest, aby nie tylko kłaść nacisk na poznanie, nabywanie wiedzy, ale również realizować działalność wychowawczą, także w formie zdalnej (Gop i Jaskulska, 2020, s. 44), mając na uwadze, że doświadczenie, jakie płynie z relacji międzyludzkich, wpływa na człowieka, determinując jego zachowania.

Ważne jest nauczanie i uczenie się w czasie pandemii, ale zdrowie, bezpieczeństwo, i dobre samopoczucie muszą być na pierwszym miejscu w pracy szkoły i nauczycieli, którzy powinni działać ze zrozumieniem życia domowego i/lub psychicznego, emocjonalnego, a także fizycznego obciążenia, z jakim borykają się ich społeczności (Doucet i in., 2020, s. 8).

\section{ZDALNY STUDENT I ROKU}

Poza wyjątkową sytuacją związaną z przygotowaniem do i zdawaniem egzaminu maturalnego studenci znaleźli się również w niecodziennej sytuacji podczas I roku studiów. Ze względu na trudną sytuację epidemiczną w kraju w październiku 2020 większość rektorów uczelni wyższych zdecydowała o zdalnym trybie edukacji. Taka decyzja skutkowała tym, iż większość studentów I roku nie miała możliwości zobaczyć się poza rzeczywistością wirtualną. Dodatkowo funkcjonowanie jako student znacznie różni się od roli ucznia. Nie mając dobrych relacji w grupie, zostali pozostawieni sami sobie w sytuacji, która była dla nich zupełnie nowa. Kolejnym czynnikiem zakłócającym jakość edukacji były problemy związane z obsługą nowoczesnych technologii.

S1: „Posiadam sprzęt i dostęp do internetu, ale z technologią się nie lubimy [...] Po prostu zawsze kliknę nie tam, gdzie trzeba, zawieszam rozmowy, ogólnie nie lubię pracować na komputerze”.

S7: „Przerażają a raczej męczą mnie bloki zajęć, mam wrażenie, że wykłady trwają i trwają a na lekcjach wiadomo było - 45 minut i koniec. Często nawet nie trwały tyle, bo jak mieliśmy zajęcia z użyciem kamerki to nauczyciele je skracali - żeby nas nie męczyć”.

S4: „Tak bardzo męczy mnie już ta zdalna edukacja, że podczas zajęć na studiach często bywam zmęczona. Chce mi się spać lub wręcz odwrotnie wiercę się i ciężko mi skupić się na przekazywanym materiale. Są prowadzący, którzy starają się urozmaicić materiał, pracujemy w grupie rozwiązujemy jakieś ciekawe problemy, ale tego jest tak niewiele, że generalnie mogę powiedzieć, że studiowanie jest nudne. Najtrudniejszy jednak jest kontakt z wykładowcami, 
oni wydają się tacy niedostępni. Kontaktujemy się najczęściej tylko przez email, zanim go napiszę to się sto razy zastanowię a czasami wolę tego nie robić, bo mam jakieś dziwne obawy”.

S2: „Na studiach jest mi bardzo trudno, po pierwsze nie mam osoby, z którą miałabym świetny kontakt. Raczej z wszystkimi dziewczynami kontaktujemy się tylko po to by ustalić jakieś kwestie związane ze studiami. Nie znamy się poza światem wirtualnym i mi to bardzo przeszkadza. Jestem osobą, która ma potrzebę by mieć zaufaną osobę, móc się z kimś skontaktować bez skrępowania. Po drugie strasznie mnie nudzą wykłady, w trakcie ich trwania skupiam się maksymalnie parę minut a później zaczynam się interesować wszystkich dookoła, przeglądam Facebooka i Instagrama, czytam wiadomości lub książkę. Wiem, że niektórzy oglądają filmy, ja nie oglądam filmów, bo się boję, że zostanę poproszona do odpowiedzi i nie zdążę filmu wyciszyć”.

Również obecna edukacja na poziomie studiów wywołuje wiele frustracji. Studenci czują się zmęczeni ciągłą niepewnością, oczekiwaniem na powrót do stacjonarnego trybu edukacji. Niewątpliwą trudnością w roli zdalnego studenta jest swego rodzaju novum, jakie doświadczają, nigdy nie byli studentami, nie znają zasad związanych z funkcjonowaniem w społeczności akademickiej. Wykładowcy akademiccy, znajdujący się również w nowej sytuacji, mogą nie dostrzegać trudności, z jakimi borykają się studenci, w ocenie studentów sprawiają oni wrażenie niedostępnych. Sposób przekazywania treści, a także długość trwania wykładów niewątpliwie wpływa niekorzystnie na odbiór studentów.

Zarówno w takcie trwania zdalnej edukacji w szkole średniej, jak i obecnie podczas studiów uczestnicy badania podkreślają, iż istotne dla jakości szeroko rozumianej edukacji potrzebne są relacje z drugim człowiekiem. Budowanie relacji wpływa na dobrostan człowieka. Zaburzenie ich jakości lub ograniczenie do powierzchownych kontaktów powoduje, iż wielu z nich czuje się zagubionych, nie odczuwa satysfakcji z okresu studiowania. Również dostosowanie metod pracy korzystnie wpływa na jakość zapamiętania i atrakcyjność prowadzonych zajęć. Zatem dobrze prowadzona edukacja zdalna wymaga działania na wielu płaszczyznach: atrakcyjności materiału, przystępności wykładowcy, pozytywnych relacji w grupie. 


\section{PODUSMOWANIE}

Obraz wyłaniający się ze zdalnej edukacji wymuszonej przez pandemię wirusa SARS-CoV-2 jest wielowymiarowy, złożony, a każde doświadczenie jednostkowe, dlatego obecnie zebrany materiał badawczy nie pozwala na tworzenie uogólnień dotyczących całego wymiaru edukacji, relacji i samopoczucia uczniów ostatniej klasy szkoły średniej oraz studentów I roku. Przeprowadzone badania pokazują jednak, że trwająca pandemia mocno odznaczyła się w dobrostanie psychicznym i fizycznym uczniów. Odpowiedzi na przedstawione pytania badawcze są mocno spolaryzowane, nie ma jednoznacznych odpowiedzi, co wymaga dalszych dociekań.

Przygotowanie do matury przebiegało w różnym tempie, uczniowie nie uzyskali jednak odpowiedniego wsparcia ze strony nauczycieli. Lekcje prowadzone były poprzez metody podające, które nie sprzyjały zapamiętaniu materiału. Kiedy nauczyciel stosował metody podające, nie potrafili skupić uwagi, koncentrowali się na innych czynnościach. Wielu z uczniów opracowało plan unikania nadmiernego przeciążania wykonywanymi zadaniami i sięgało do gotowych rozwiązań.

Każdy uczestnik badania przeżywał inne trudności związane z edukacją w formie zdalnej, największą z nich było doświadczenie ciągłego lęku, zachwianie dobrostanu psychicznego i fizycznego. Znacznie obniżyła się motywacja uczniów do nauki, co powodowało trudność w przygotowaniu się do matury.

Czas zdalnej edukacji zweryfikował również relacje rówieśnicze, wielu z nich doświadczyło mocnego obniżenia ich jakości lub całkowitego zaniku. Pojawiające się trudności, niepewność generowały również konflikty, które nie zostały w odpowiedni sposób zakończone, co również determinowało jakość relacji. Zdecydowana większość studentów określa jednak, iż była to pozytywna weryfikacja przyjaźni i pozostały tylko te, które są warte utrzymania. Obecnie studenci wskazują, iż relacje na poziomie studiów ograniczają się tylko do kontaktów związanych z zajęciami na uczelni. Większość studentów nie zna się, nigdy nie widziała się poza komputerem, nie kontaktuje się prywatnie.

Wiele wyzwań stoi przed polską szkołą, która po pandemii nie będzie już taka sama. Mimo iż wielu uczniów deklaruje chęć powrotu do szkoły, jej obraz kształtuje się zupełnie inaczej. Każdy nauczyciel z tego okresu wyniósł inne doświadczenia; dla jednych będzie to czas, o którym chcieliby jak najszybciej zapomnieć, inni natomiast uczestniczyli w wielu szkoleniach, udoskonalili swój warsztat i nie będą już takimi samymi nauczycielami. Również uczniowie będą oczekiwali większego wsparcia, naprawienia relacji, ale także integracji z grupą. 
Wobec całej społeczności akademickiej również oczekuje się zmiany metod nauczania, organizacji zajęć, a także form kontaktu; niewątpliwie ważne jest, by wykładowcy dawali studentom pole do poznawania się, integracji i budowania relacji. Obecna sytuacja społeczna i ekonomiczna jest stresogenna, dlatego warto w ramach zajęć w szkole i na studiach zrezygnować z tworzenia dodatkowych sytuacji lęku i niepewności, tworzyć za to atmosferę przyjazną poznaniu, twórczemu i krytycznemu myśleniu.

\section{Bibliografia}

Doucet, A., Netolicky, D., Timmers, K., Tuscano, F. J. (2020). Thinking about pedagogy in an unfolding pandemic (An Independent Report on Approaches to Distance Learning during COVID-19 School Closure) (2.0). Work of Education International and UNESCO.

Gop, A., Jaskulska, S. (2020). Kształcenie na odległość a rozwój kompetencji cyfrowych uczniów i ich rodziców w świetle wyników badań - w kierunku nowej szkoły. Studia Edukacyjne, 58.

Jaszczyszyn, E., Szada-Borzyszkowska, J. (2010). Edukacja dziecka: Mity i fakty. Białystok: Trans Humana.

Kaczmarzyk, M. (2020). Neurobiologiczny kontekst edukacji zdalnej. W: J. Pyżalski (red.), Edukacja w czasach pandemii wirusa COVID-19. Z dystansem o tym, co robimy obecnie jako nauczyciele. EduAkcja Sp. z o.o.

Klus-Stańska, D., Nowicka, M. (2005). Sensy i bezsensy edukacji wczesnoszkolnej. Warszawa: WSiP - Wydawnictwa Szkolne i Pedagogiczne.

Kvale, S. (2004). InterViews wprowadzenie do jakościowego wywiadu badawczego (Wyd. 1). Białystok: Trans Humana.

Meeter, M., Bele, T., Hartogh, C., Bakker, T., de Vries, R.E., Plak, S. (2020). College students' motivation and study results after COVID-19 stay-at-home orders [Preprint]. PsyArXiv. Download: https://doi.org/10.31234/osf.io/kn6v9.

Plebańska, M., Szyller, A., Sieńczewska, M. (2021). Co zmieniło się w edukacji zdalnej podczas trwania pandemii? Raport z badania. Warszawa: Wydział Pedagogiczny Uniwersytetu Warszawskiego.

Poleszak, W., Pyżalski, J. (2020). Psychologiczna sytuacja dzieci i młodzieży w dobie epidemii. W: J. Pyżalski (red.), Edukacja w czasach pandemii wirusa COVID-19. $Z$ dystansem o tym, co robimy obecnie jako nauczyciele. EduAkcja Sp. z o.o.

Ptaszek, G., Pyżalski, J. Ł., Dębski, M., Stunża, G. D., Bigaj, M. (2020). Edukacja zdalna: Co stało się z uczniami, ich rodzicami i nauczycielami. Gdańsk: Gdańskie Wydawnictwo Psychologiczne.

Pyżalski, J. (red.). (2020). Edukacja w czasach pandemii wirusa COVID-19. Z dystansem o tym, co robimy obecnie jako nauczyciele. EduAkcja Sp. z o.o.

Spitzer, M. (2014). Jak uczy się mózg. Warszawa: Wydawnictwo Naukowe PWN.

Zaccoletti, S., Camacho, A., Correia, N., Aguiar, C., Mason, L., Alves, R. A., Daniel, J. R. 
(2020). Parents' Perceptions of Student Academic Motivation During the COVID-19 Lockdown: A Cross-Country Comparison, Frontiers in Psychology, 11, 592670. Download: https://doi.org/10.3389/fpsyg.2020.592670.

Żylińska, M. (2013). Neurodydaktyka: Nauczanie i uczenie się przyjazne mózgowi. Toruń: Wydawnictwo Naukowe Uniwersytetu Mikołaja Kopernika. 